\title{
The Effect of Astaxanthin Administration on Plasma Levels of Tumor Necrosis Factor- $\alpha$ and Palatine Tonsil Swab in Chronic Tonsillitis Patients
}

\author{
Sutji Pratiwi Rahardjo ${ }^{1}$, Abd. Azis Rola ${ }^{1}$, Abdul Qadar Punagi ${ }^{1}$, Muh Fadjar Perkasa ${ }^{1}$ \\ ${ }^{1}$ Ear, Nose, Throat, Head and Neck Surgery Department, Medical Faculty Hasanuddin University, \\ Makassar-Indonesia
}

\begin{abstract}
Background: Chronic tonsillitis is chronic inflammation of the palatine tonsils which can be caused by the presence of free radicals that stimulate the formation of pro-inflammatory cytokines such as Tumor Necrosis Factor- $\alpha$ (TNF- $\alpha$ ) and interleukin-6 (Il-6). Astaxanthin as an antioxidant and anti-inflammatory is thought to reduce levels of proinflammatory cytokines.
\end{abstract}

Aim: To determine plasma levels of TNF- $\alpha$ and palatine tonsill smears in patients with chronic tonsillitis before and after administration of astaxanthin.

Method: Research with clinical trial design. Thirty-one subjects who met the inclusion and exclusion criteria in the Ear, Nose, Throat, Head and Neck Surgery clinic in Wahidin Sudirohusodo Hospital and Network Hospital were given astaxanthin $4 \mathrm{mg}$ /day for 14 days. Plasma TNF- $\alpha$ levels and palatine tonsile smears were examined before and after administration of astaxanthin. Data were analyzed using SPSS $25^{\text {th }}$ version. The statistical tests used Paired-t test and Independent-t test.

Results: Thirty-one subjects can be followed until the end of the study. Astaxanthin $4 \mathrm{mg}$ per day for 14 days can reduce plasma TNF- $\alpha$ levels and palatine tonsil swab of patients with chronic tonsillitis $(p<0.05)$, and there is no significant difference in TNF- $\alpha$ levels between plasma and palatine tonsil swab both before and after administration astaxanthin $(\mathrm{p}>0.05)$.

Conclusion: Astaxanthin can reduce plasma TNF- $\alpha$ levels and palatine tonsil swab in chronic tonsillitis patients.

Keywords: Chronic tonsillitis, Tumor Necrosis Factor- $\alpha$ (TNF- $\alpha$ ), TNF- $\alpha$ levels, palatine tonsil swab, astaxanthin.

\section{Introduction}

Chronic tonsillitis is chronic inflammation of the palatine tonsils caused by bacterial or viral infections and can affect all ages, but predominantly occurs in children. Chronic tonsillitis is the most common disease of all recurrent throat inflammation. ${ }^{1}$

Free radicals are one of the factors involved in the pathogenesis of chronic tonsillitis. Free radicals can stimulate the formation of proinflammatory cytokines such as TNF- $\alpha$ and IL- 6 . TNF- $\alpha$ is the main cytokine in the inflammatory response to bacteria and other microbes. The main sources of TNF- $\alpha$ are macrophages, mononuclear phagocytes and antigen-activated T cells, NK cells (Natural Killer), and mast cells. ${ }^{2,3}$

Cytokine measurements are generally done through blood tests and biopsies, but currently cytokine tests can be done using smears. A swab technique is generally used to examine microorganisms in mucosal tissue by making smears on the mucosal surface 3-5 times to take microorganisms or exfoliate cells in the area., ${ }^{4,5}$

To inhibit and neutralize free radicals, the body forms antioxidants to prevent cell damage. The mechanism 
of inhibition of antioxidants usually occurs by giving one electron to become a more stable compound. Antioxidants can also act as anti-inflammatory agents by inhibiting increased production of cytokines such as interleukin-6 (Il-6) or Tumor Necrosis Factor- $\alpha$ (TNF- $\alpha$ ) which are proinflammatory cytokines. ${ }^{2,3,6,7}$

Astaxanthin is an antioxidant group of carotenoids which also has anti-inflammatory activity by inhibiting the production of cytokines, such as TNF- $\alpha$, prostaglandin E-2 (PGE-2), IL-6 and Nitric oxide (NO). As an anti-inflammatory, astaxanthin inhibits the production of inflammatory mediators by blocking the activation pathway of Nuclear Factor-k $\beta(\mathrm{NF}-\mathrm{k} \beta) .{ }^{8,9,10,11}$

\section{Method}

This research was conducted at the ENT-HN clinic at Wahidin Sudirohusodo Hospital and the Network Hospital. The time of the study began from August 2019 to October 2019. This study was approved by the Health Research Ethics Commission ofRSPTN UH-RSWS (No: 647/UN4.6.4.5.31/PP36/2019).

The design of this study was clinical trial. The subject collection technique is carried out randomly until a specified amount is reached. In this study the number of subjects was 31. Subjects were chronic tonsillitis sufferers who met the inclusion criteria, namely age 1240 years, did not consume antioxidant supplementation in the last 1 month, did not consume seafood and were willing to participate in research with give written consent (Informed Consent) and sign a letter of approval for medical treatment. Exclusion criteria are has systemic or metabolic diseases, has infectious diseases other than chronic tonsillitis, has lower respiratory tract diseases, has head and neck tumors, has allergic diseases and active smokers. Drop Out Criteria are the patient did not come in control, did not regularly take astaxanthin, or has chronic exacerbation of chronic tonsillitis during the study.

A total of 31 subjects were taken by the median cubital venous blood and palatine tonsile surface smears for examination of TNF- $\alpha$ levels. After that, $4 \mathrm{mg}$ of astaxanthin therapy was given once a day for 14 days. On the 15th day, venous blood was taken again through median cubite vein and the palatine tonsilswab was examined for TNF- $\alpha$ levels.

Measurement of plasma TNF- $\alpha$ levels and palatine tonsill swab was carried out in the Molecular Biology laboratory of the Hasanuddin University Hospital using the Enzym Linked Immunosorbent Assay (ELISA) method. Data analysis was performed using SPSS $25^{\text {th }}$ version. The statistical tests used were Paired-t test and Independent-t test.

\section{Results}

This research was conducted at the ENT-HN clinic at Wahidin Sudirohusodo Hospital and the Network Hospital during the period August to October 2019. All subjects followed the study to completion. Data analysis was performed using SPSS $25^{\text {th }}$ version. The statistical test used was the Paired-t test to compare TNF- $\alpha$ levels before and after administration of astaxanthin and the Independent-t test to compare plasma TNF- $\alpha$ levels with palatine tonsil swab. The results of the test were statistically significant if the $p$ value $<0.05$.

Data analysis was performed on 31 subjects aged between 21-37 years with a mean of $27.7 \pm 4.6$ years. The distribution of subject characteristics is shown in the following table:

Table 1. Distribution of Samples by Sex

\begin{tabular}{|l|c|c|}
\hline Sex & $\mathbf{n}$ & $\mathbf{\%}$ \\
\hline Male & 13 & 41,9 \\
\hline Female & 18 & 58,1 \\
\hline Total & $\mathbf{3 1}$ & $\mathbf{1 0 0 , 0}$ \\
\hline
\end{tabular}

From table 1 it was found that the most sex in this study were 18 female samples $(58.1 \%)$, while 13 male samples $(41,9 \%)$.

Table 2. Distribution of Samples by Age

\begin{tabular}{|l|c|c|}
\hline Age (Years) & $\mathbf{n}$ & $\mathbf{\%}$ \\
\hline $21-25$ & 12 & 38,7 \\
\hline $26-30$ & 9 & 29,0 \\
\hline $31-35$ & 9 & 29,0 \\
\hline $36-40$ & 1 & 3,3 \\
\hline Total & $\mathbf{3 1}$ & $\mathbf{1 0 0 , 0 0}$ \\
\hline
\end{tabular}

Table 2 shows that the age of the samples varied between 21 to 37 years with the most samples in the 2125 year age group of 12 samples $(38.7 \%)$ followed by the 26-30 year age group of 9 samples $(29.0 \%)$, then the groups aged $30-35$ years as many as 9 samples $(29.0 \%)$ and at least found in the age group 36-40 years with a total sample of 1 sample (3.3\%). 
Table 3. Comparison of TNF- $\alpha$ levels before and after administration of Astaxanthin

\begin{tabular}{|l|l|c|c|c|c|}
\hline Sample & Time & n & Mean & SD & p \\
\hline \multirow{2}{*}{ Plasma } & Before & 31 & 122,8 & 155,1 & 0,049 \\
\cline { 2 - 6 } & After & 31 & 99,5 & 116,3 & \\
\hline \multirow{2}{*}{ Palatine Tonsils Swab } & Before & 31 & 126,6 & 16,5 & 0,000 \\
\cline { 2 - 6 } & After & 31 & 62,7 & 23,4 & \\
\hline
\end{tabular}

Table 3 shows the comparison of TNF- $\alpha$ levels before and after administration of astaxanthin. In plasma, a significant reduction in TNF- $\alpha$ levels was found after astaxanthin administration compared to before, namely from 122.8 to 99.5 or there was a decrease of 23.3 $(19.0 \%)$. From the paired-t test results obtained $p$ value
$<0.05$. In the palatine tonsil swab, a significant decrease in TNF- $\alpha$ levels was found after administration of astaxanthin compared to before, ie from 126.6 to 62.7 or there was a decrease of $63.9(50.5 \%)$ with paired-t test, the value of $p<.001$.

Table 4. Comparison of TNF- $\alpha$ Plasma and Palatine Tonsil Swab

\begin{tabular}{|l|l|c|c|c|c|}
\hline Time & Sample & $\mathbf{n}$ & Mean & SD & p \\
\hline \multirow{2}{*}{ Before } & Plasma & 31 & 122,8 & 155,1 & 0,891 \\
\cline { 2 - 6 } & Palatine Tonsil Swab & 31 & 126,6 & 16,5 & \\
\hline \multirow{2}{*}{ After } & Plasma & 31 & 99,5 & 116,3 & 0,094 \\
\cline { 2 - 6 } & Palatine Tonsil Swab & 31 & 62,7 & 23,4 & \\
\hline
\end{tabular}

Independent-t test: Table 4 shows a comparison of plasma TNF- $\alpha$ levels and palatine tonsil swab. Before giving astaxanthin, there was no significant difference in plasma TNF- $\alpha$ levels with palatine tonsil swab. From the independent- $t$ test, $p$ value $>0.05$ was obtained. After administration of astaxanthin, the mean TNF- $\alpha$ level in plasma (99.5) was higher than in palatine tonsil swab (62.7), but the results of statistical tests showed that the difference was not significant, with a $\mathrm{p}$ value $>0.05$.

\section{Discussion}

In this study, there were 31 patients with chronic tonsillitis who took blood samples from the cubital median vein and palatine tonsil swab for examination of TNF- $\alpha$ levels.

Table 1 shows the distribution of samples according to sex. that is, a higher proportion of women (58.1\%) compared to men $(41.9 \%)$. This is in accordance with research conducted by Yuliani et al (2015) in which chronic tonsillitis sufferers found more in women (76\%) than men (24\%). Fakh et al (2016) also found more chronic tonsillitis sufferers in women $(56 \%)$ than men (44\%). Different results were obtained from the research of Sembiring et al (2013). From 20 samples, it was found that male sex was $55 \%$, while female was $45 \%$. Likewise in the study of Umami et al (2017). Of the 40 chronic tonsillitis patients, $23(57.5 \%)$ were male and 17 (42.5\%) female. ${ }^{7,12,13}$

There are differences regarding the gender that is predominantly suffering from chronic tonsillitis. Several factors have been investigated including genetic factors and cultural differences, but there is no genetic and cultural involvement involved in sex differences that often experience chronic tonsillitis. So it can be concluded that there are no factors that affect gender differences in chronic tonsillitis. This is likely only the influence of the population in a population related to the predominance of certain sexes on the incidence of chronic tonsillitis, both men and women. ${ }^{13}$

From table 2 shows the distribution of samples by age group. The most age group in this study was age $21-25$ years $(38.7 \%)$. This is consistent with research conducted by Asyari et al (2019). From 96 samples, the highest number of samples obtained in the age group of 19-25 years was $36(37.50 \%)$. Chronic tonsillitis is one of the most common ENT diseases, especially in 
children and adolescents. There are many similarities in age range between studies. From a study conducted by Sapitri (2013) about the characteristics of chronic tonsillitis sufferers indicated by tonsillectomy at RadenMattaher Hospital in Jambi, from the 30 samples obtained the most distribution aged 5-14 years (50\%). In America, chronic tonsillitis is often found in children aged 5-10 years and young adults aged 15-25 years. In Scotland, the most common age of patients with chronic tonsillitis is $14-29$ years, which is $50 \%$ of the population. Whereas in Russia the most common age of chronic tonsillitis sufferers is 15-30 years. Many factors that cause chronic tonsillitis are more common in children. The greatest immunological activity of tonsils is found at the age of 3-10 years. At school age, starting from the age of 5 years, children are more susceptible to viral and bacterial infections from the surrounding environment. One of the predisposing factors for chronic tonsillitis is the influence of several types of food, this is because children often consume foods with artificial sweeteners, containing many preservatives and poor oral care. In children also often suffer from acute respiratory infections or due to acute tonsillitis that is not treated adequately or left alone without treatment. ${ }^{13,14}$

In this study found a decrease in TNF- $\alpha$ levels after administration of astaxanthin for 14 days both in plasma and palatine tonsil swab. In plasma, a significant decrease in TNF- $\alpha$ was found at 23.3 (19.0\%), from 122.8 to $99.5(\mathrm{p}<0.05)$. Likewise in the palatine tonsil swab, a significant reduction in TNF- $\alpha$ levels was found from 126.6 to 62.7 or a decrease of 63.9 $(50.5 \%)(p<0.001)$. The decrease in TNF- $\alpha$ levels is caused by administration of astaxanthin which acts as an anti-inflammatory by inhibiting the production of inflammatory mediators by blocking the activation pathway of Nuclear Factor-k $\beta$ (NF-k $\beta$ ). Research conducted by Nobles (2012) found that astaxanthin has an anti-inflammatory effect which is characterized by a decrease in neutrophil and lymphocyte levels. Another study conducted by Ohgami et al (2003) about the potential of astaxanthine in inflammation shows that astaxanthin can reduce the production of Nitric Oxide, prostaglandin E2 and Tumor Necrosis Factor- $\alpha$ (TNF- $\alpha$ ) in vitro in mouse macrophage cells. Another study by Lee et al (2003) which states that astaxanthine can inhibit the expression and formation of proinflammatory cytokine mediators such as TNF- $\alpha$ and IL-1. Aside from being an anti-inflammatory, astaxanthin is also known as an antioxidant. Astaxanthin can reduce reactive oxygen species (ROS) so as to reduce lipid peroxidation. Astaxanthin reacts with peroxyl or hydroxyl free radicals so that they are no longer harmful to the body. Thus the content of free radicals can be reduced. ${ }^{9,15}$

Before administration of astaxanthin there was no significant difference in plasma TNF- $\alpha$ levels with palatine tonsil swab. After administration of astaxanthin, the average TNF- $\alpha$ level in plasma (99.5) was higher than in the palatine tonsil swab (62.7), but the results of statistical tests showed that the difference was not significant. This shows that there is a correlation of TNF- $\alpha$ levels between plasma and palatine tonsil swab. This is consistent with research conducted by Yusran et al (2011) regarding the correlation of TNF- $\alpha$ levels between examination of swab lesions with peripheral blood tests. From this study it was found that there was a correlation between TNF- $\alpha$ levels in peripheral blood and ulcer swab of Recurrent Stomatitis Aftosa Stomatitis patients. The correlation between TNF- $\alpha$ levels of palatine tonsil swab and plasma TNF- $\alpha$ levels of chronic tonsillitis patients suggests the possibility of using swab techniques to calculate cytokine levels, especially TNF- $\alpha$ in other studies to replace venous punksi techniques for blood specimen collection or biopsy techniques. ${ }^{4,5}$

The conclusion of this study is that administration of astaxanthin can reduce plasma TNF- $\alpha$ levels and palatine tonsil swab with chronic tonsillitis. There is a correlation between plasma TNF- $\alpha$ levels with swab of palatine tonsil with chronic tonsillitis both before and after administration of astaxanthin.

It is recommended that the administration of additional astaxanthin therapy as an anti-inflammatory can be considered in the management of chronic tonsillitis. The swab technique can be used to calculate cytokine levels, especially TNF- $\alpha$ in patients with chronic tonsillitis to replace venous puncture techniques or biopsy techniques.

Ethical Clearance: Taken from Medical Faculty Ethical committee

Source of Funding: Self

Conflict of Interest: Nil

\section{References}

1. Ramadhan F, Sahrudin, Ibrahim K. Analisis Risiko Kejadian Tonsilitis Kronispada Anak Usia 5-11 Tahun di Wilayah Kerja Puskesmas Puuwatu Kota 
Kendari Tahun 2017. JurnalIlmiah Mahasiswa Kesehatan Masyarakat. Vol. 2. 2017; 6: 1-8.

2. Parwata IMOA. Bahan Ajar Bioaktivitas: Antioksidan. Bali: Program Pasca Sarjana Universitas Udayana. 2015.

3. Zheng W, Wang SY. Antioxidant Activity and Phenolic Compounds in Selected Herbs. ACS Publications. 2009; 49 (11) : 5165-5170.

4. Yusran A, Marlina E, Sumintarti. Adanyakorelasikadar TNF- $\alpha$ antarapemeriksaanhapusanlesidenganpemeriksaandarahperiferpasien stomatitis aftosarekuren. Dentofasial. 2011; 10(2): 71-75.

5. Marlina E. Teknikhapusanmukosamulutpadaulser RAS minor melaluiperbedaankadar TNF- $\alpha$ dan IL10. Tesistidakditerbitkan. Surabaya: Universitas Airlangga. 2010.

6. Cvetkovic T, Vlahovic P, Todorovic M, Stankovic M. Investigation Oxidative Stress in Patient with Chronic Tonsilitis. Auris Nasus Larynx. 2009; 36: 340-344.

7. Umami VM, Suprihati, Farokah. Pengaruh Vitamin C Dosis Tinggi Terhadap Peroksidasi Lipid dan Penyembuhan Luka Pasca Tonsilektomi. ORLI Vol. 47 2017; 1: 58-64.

8. Hussein G, Sankawa U, Goto H, Matsumoto K, Watanabe H. Astaxantin, a carotenoid with potential in human health and nutrition. J. Nat. Prod. Vol 69. 2006; pp. 443-449.

9. Lee SJ, Bai SK, Lee KS. Astaxantin Inhibits Nitric Oxide Production and Inflammatory Gene
Expression by Suppressing IкB Kinase-dependent NF-kB Activation. Mol. Cells. 2003; 16: 97-105.

10. Bangsawan PI. Efekantiinflamasi Astaxantinterhadap volume edema danekspresi cox-2 denganpenggunaan parameter limfositdanneutrofilpadatikusputihdewasagalurwistar. Tesistidakditerbitkan. Universitas Sriwijaya. Fakultas Kedokteran. Palembang. 2012.

11. Kusumastuty I, Adi P, Budhi L, Ari F. PengaruhPemberianDaunUbiJalarUngu (Ipomoea batatas Lam) terhadap Kadar TNF-A, Il-6 danNfKbpada Tikus yang Dipapar Asap Rokok. Jurnal Kedokteran Brawijaya, Vol. 28. 2015; 3: 228-232.

12. Yuliyani EA., Nuaba IGA, Ratnawati LM, Setiawan EP. Distribusi Penderita Tonsilitis Kronis Yang Telah Menjalani Tonsilektomi Di Rsup Sanglah Denpasar Periode Januari 2014-September 2015. BagianIlmu Kesehatan THT-KL Fakultas Kedokteran Universitas Udayana. Denpasar. 2015.

13. Fakh IM, Novialdi, Elmatris. Karakteristik Pasien Tonsilitis Kronispada Anak di Bagian THT-KL RSUP Dr. M. Djamil Padang Tahun 2013. Jurnal Kesehatan Andalas. 2013; 5(2): 436-442.

14. Sapitri RV. Karakteristik Penderita Tonsilitis Kronis Yang Diindikasikan Tonsilektomi Di RSUD Raden Mattaher Jambi. Jambi. Universitas Jambi. 2013.

15. Aisoi L. Karakteristik Astaxantin Sebagai Antioksidan. Program Studi Pendidikan Biologi. Universitas Cenderawasih Jayapura. Novae Guinea Jurnal Biologi. 2016; 1: 43-51. 